\title{
Eunuchs in the East, Men in the West? Dis/unity, Gender and Orientalism in the Fourth Century
}

\author{
Shaun Tougher
}

\section{Introduction}

In the narrative of relations between East and West in the Roman Empire in the fourth century $\mathrm{AD}$, the tensions between the eastern and western imperial courts at the end of the century loom large. The decision of Theodosius I to "split" the empire between his young sons Arcadius and Honorius (the teenage Arcadius in the east and the ten-year-old Honorius in the west) ushered in a period of intense hostility and competition between the courts, famously focused on the figure of Stilicho. ${ }^{1}$ Stilicho, half-Vandal general and son-in-law of Theodosius I (Stilicho was married to Serena, Theodosius' niece and adopted daughter), had been left as guardian of Honorius, but claimed guardianship of Arcadius too and concomitant authority over the east. In the political manoeuvrings which followed the death of Theodosius I in 395, Stilicho was branded a public enemy by the eastern court. In the war of words between east and west a key figure was the (probably Alexandrian) poet Claudian, who acted as a 'propagandist' (through panegyric and invective) for the western court, or rather Stilicho. Famously, Claudian wrote invectives on leading officials at the eastern court, namely Rufinus the praetorian prefect and Eutropius, the grand chamberlain (praepositus sacri cubiculi), who was a eunuch. It is Claudian's two attacks on Eutropius that are the inspiration and central focus of this paper which will examine the significance of the figure of the eunuch for the topic of the end of unity between east and west in the Roman Empire.

Eunuchs became an institutional feature of the imperial court in the late Roman period. ${ }^{2}$ This phenomenon was especially associated with the east, an

1 For recent treatment of Stilicho see Natalie Kampen, Family Fictions in Roman Art (Cambridge, Eng., 2009), pp. 123-38.

2 See for instance Keith Hopkins, "Eunuchs in Politics in the Later Roman Empire," Proceedings of the Cambridge Philological Society 189 (1963), 62-80, slightly revised in his Conquerors and Slaves (Cambridge, Eng., 1978), pp. 172-96; Peter Guyot, Eunuchen als Sklaven und Freigelassene in der griechisch-römischen Antike (Stuttgart, 1980), pp. 130-76; and Shaun Tougher, The Eunuch in Byzantine History and Society (London and New York, 2008), pp. 36-53.

(C) SHAUN TOUGHER, 2015 | DOI 10.1163/9789004291935_010

This is an open access chapter distributed under the terms of the Creative Commons AttributionNoncommercial 3.o Unported (CC-BY-NC 3.o) License. 
association Claudian dwells on in his invectives on Eutropius. I will examine how Claudian presents Eutropius and how he utilises the eunuch to emphasise the contrast between east and west. In Greek and Roman writing there was a long history of deploying the figure of the eunuch (whose gender, as a castrated male, was ambiguous) as a marker and symbol of the feminine and effeminate east as opposed to the 'normal' masculine west. I will consider the roots of such orientalist discourse, but also consider its validity. I will ask, to what extent were court eunuchs an eastern phenomenon, and whether we see an end to unity between east and west in the matter of the nature of the imperial courts in relation to the use of eunuchs. I will argue that the situation is more complicated than the simple contrast Claudian creates, and that continuity of practice across both parts of the empire persisted beyond the fourth century. The orientalist discourse needs to be recognised, addressed and corrected, for modern historians themselves can compound its potency; in his inaugural lecture, on Claudian, Oswald Dilke summed up parts of the invectives on Eutropius as follows:

The so-called patrician has been nothing but a pander and a punkahwalla, who fanned an empress with peacock's feathers ... Statues of this Pooh-Bah appear all over Constantinople, as judge, as consul, even as general, one of them dominating the senate-house. ${ }^{3}$

He adds later orientalist imagery to an already heady mix. Eunuchs were not just an eastern phenomenon, though it was easy to brand them as such. In reality they were a defining feature of Roman culture.

\section{Claudian and Eutropius}

The figures of Claudian and Eutropius, and their role in the history of the Roman Empire at the end of the fourth century, are well known. Claudian was the subject of a major monograph by Alan Cameron published in 1970. ${ }^{4}$ More recently, he has received scrutiny from Catherine Ware in her Claudian and the Roman Epic Tradition. ${ }^{5}$ The significance of the poet for court politics and

3 Oswald Ashton Wentworth Dilke, Claudian: Poet of Declining Empire and Morals; An Inaugural Lecture (Leeds, 1969), p. 14.

4 Alan Cameron, Claudian. Poetry and Propaganda at the Court of Honorius (Oxford, 1970).

5 Catherine Ware, Claudian and the Roman Epic Tradition (Cambridge, Eng., 2012). For other recent work on Claudian see for instance Marie-France Guipponi-Gineste, Claudien. Poète du monde à la cour d'Occident (Paris, 2010); Florence Garambois-Vasquez, Les invectices de Claudian. Une poétique de la violence (Brussels, 2007). 
culture of the late fourth and early fifth centuries is not in doubt, given his prolific output of panegyric and invective; he was also celebrated in his own day, a statue of him being erected in Rome in the Forum of Trajan, in the names of Arcadius and Honorius. ${ }^{6}$

As for Eutropius, he was a product of the trade in eunuch slaves and rose to become the leading minister of Arcadius, though he had served Theodosius I too (undertaking for him a mission to Egypt). ${ }^{7} \mathrm{He}$ was Arcadius' grand chamberlain, and replaced Rufinus as the emperor's right hand man in 395. The political importance of the eunuch - and Stilicho - is strikingly conveyed by a fragment of the lost history of their contemporary Eunapius, which reflects on the difficulty of acquiring good information about affairs in the west in "the time of Eutropius". Eunapius observes:

If any officials or soldiers had access to information on political activity, they related it as they wished, biased by friendship or hostility or a desire to please someone. And if you brought together three or four of them with conflicting versions as witnesses, there would be a great argument which would proceed from passionate and heated interjections to a pitched battle. They would say, 'Where did you get this from?' 'Where did Stilicho see you?' 'Would you have seen the eunuch?' so that it was quite a task to sort out the tangle. ${ }^{8}$

Eutropius' pre-eminence is also reflected by the number of statues and other images of him that were produced, and by his appointment as consul for $399 .{ }^{9}$ The usefulness of Eutropius as an example of the powerful court eunuchs who characterise later Roman and Byzantine history means that he has featured heavily in modern discussions of the phenomenon, such as studies by James Dunlap and Helga Scholten. ${ }^{10}$

6 CIL VI.1710. The inscription identifies Claudian as a vir clarissimus, tribune and notary.

7 For Eutropius see for instance PLRE 2, Eutropius 1, pp. 440-44; James E. Dunlap, "The Office of the Grand Chamberlain in the Later Roman and Byzantine Empires," in Two Studies in Later Roman and Byzantine Administration (New York and London, 1924), pp. 161-324, esp. pp. 272-84.

8 Eunapius, History, Fragment 66.2, trans. Roger Blockley, The Fragmentary Classicising Historians of the Later Roman Empire: Eunapius, Olympiodorus, Priscus and Malchus, 2 (Liverpool, 1983), p. 103 .

9 For statues and images of Eutropius see Claudian, In Eutropium 2.72-77, and Codex Theodosianus 9.40.17.

10 Dunlap, "Grand Chamberlain"; Helga Scholten, Der Eunuch in Kaisernähe: zur politischen und sozialen Bedeutung des praepositus sacri cubiculi im 4. und 5. Jahrhundert n. Chr. (Frankfurt, 1995). 
The duo of Claudian and Eutropius are nicely brought together, of course, because Claudian wrote two invectives on the eunuch. ${ }^{11}$ The first was elicited by the designation of Eutropius as consul for 399, and the second completed following the eunuch's sudden fall and exile to Cyprus in the same year. These texts are certainly not neglected by historians and classicists for they reveal much about the career of Eutropius, concepts of the gender identity of eunuchs, and the political and literary context of the time; they are, for instance, the focus of Jacqueline Long's wonderfully subtitled Claudian's In Eutropium. Or, How, When, and Why to Slander a Eunuch (Chapel Hill and London, 1996). ${ }^{12}$ Such is the importance of these texts for East-West relations and concepts that they deserve a place in this volume.

In his invectives on Eutropius Claudian dwells heavily on the gender identity of the eunuch, presenting him in a range of guises: as woman, as man, and as other - a third gender..$^{13}$ The image of Eutropius as a woman appears at the very start of the first invective, Claudian exclaiming "O shame to heaven and earth! Our cities behold an old woman (anus) decked in a consul's robe who gives a woman's name to the year" (1.9-10), and he begs "at least give us a man (virum)" (1.29)..$^{14}$ Eutropius' military role provides Claudian with ammunition for his assault. He asserts:

Mars blushed, Bellona scoffed and turned her from the disgrace of the East whene'er with arrows strung and flashing quiver the aged Amazon practises battles or hurries back as arbiter of peace and war to hold parley with the Getae. Our enemies rejoiced at the sight and felt that at last we were lacking in men (viros) (1.238-43).

Claudian declares that Eutropius should not have intruded on the male arena of warfare, but busied himself with the female craft of spinning

$11 \quad$ For an edition and translation see Maurice Platnauer, Claudian, 1 (Cambridge, Mass., 1922), pp. 138-229.

12

See also the commentary (and German translation) by Helge Schweckendiek, Claudians Invektive gegen Eutrop (In Eutropium). Ein Kommentar (Hildesheim, 1992). There are also important observations in Alan Cameron, "Notes on Claudian's Invectives," Classical Quarterly 18 (1968), 387-411, esp. 399-411, and his Claudian, pp. 124-55. Eunuchs," in Changing Sex and Bending Gender, eds. Alison Shaw and Shirley Ardener (New York and Oxford, 2005), pp. 60-73. archaic in style, the translation has elegance and impact. 
(1.274). ${ }^{15}$ Eutropius' acting as a man is also reflected by Claudian characterising the eunuch as the father of the emperor Arcadius (2.50). Especially striking though, Claudian identifies Eutropius as neither man nor woman, and has Roma describe eunuchs as an "Unhappy band...whom the male sex has discarded and the female will not adopt" (infelix turba...alter quos pepulit sexus nec suscipit alter) (1.466-7).

The invectives also make great play with issues of east and west, and the different identities of east and west. This raises issues of gender too, for the west is characterised as masculine and manly, and the east as feminine and effeminate. This gender agenda is of course well served by the figure of the eunuch as it is so much associated with the east. Claudian ascribes the invention of eunuchs to the Assyrian queen Semiramis (in order to disguise her sex by surrounding herself with womanly men) (1.339-42). He also notes that it was Parthian custom to castrate boys prior to puberty "to serve their lusts by thus lengthening the years of youthful charm" (1.342-5). When Roma speaks in the first invective - on hearing the news of Eutropius' consulship she flies to the camp of Honorius where with Stilicho the emperor is receiving Germans who had come to conclude a peace (1.371-80) - she acknowledges that eunuchs are part of Rome now but that they originated in the east; she confesses she has "long learned to tolerate" the "genus" of eunuchs, "ever since the court exalted itself with Arsacid pomp and the example of Parthia corrupted our morals" (1.414-16). The eastern practice of eunuchising boys (as well as Eutropius' eastern origin) is stressed by the fact that Eutropius was castrated by an Armenian (1.47) and put up for sale in Assyrian markets (1.58).

The contrast between east and west is emphasised by Roma when she speaks to Honorius. Lauding the military success of the west and lamenting the situation in the east, she remarks that the east, unlike the west, is used to having women as rulers, and thus can accept eunuchs as governors. She exclaims: "why disfigure warlike Italy with the general brand and defile her austere peoples with their deadly profligacy? Drive this foreign pollution (peregrina piacula)" out of Latium, "suffer not this thing of shame to cross the Alps; let it remain fixed in the country of its birth" (1.427-33). The contrast between the effeminate east and the manly west is also stressed by Roma when she asserts that eunuchs "now despise the fan and aspire to the consul's cloak. No longer do they carry the maidenly parasol for they have dared to wield the axes of Latium" (1.463-5). (Interestingly, Claudian compounds the eastern

The idea of the appropriateness of a eunuch engaged in the female task of spinning also surfaces in the case of Narses, the famous sixth-century grand chamberlain and general: see below. 
effeminacy versus western manliness imagery by tapping into the religious identity of eunuchs too, not just their identity as eastern court officials, as the infamous galli, the supposedly self-castrating devotees of the Great Mother, the goddess Cybele, whose cult had been imported from Asia into Rome in 204 ${ }^{\mathrm{BC}^{16}}$ ) Elsewhere, however, Claudian remarks on the unusualness of the position of Eutropius, even in the east. He declares $(1.296-7)$ "no country has ever had a eunuch for a consul or judge or general", and

Had a woman assumed the fasces, though this were illegal it were nevertheless less disgraceful. Women bear sway among the Medes and swift Sabaeans: half barbary (barbariae) is governed by martial queens. We know of no people who endure a eunuch's rule $(1.320-324) .{ }^{17}$

It is also noteworthy that Claudian - in relation to Eutropius selling governorships of the eastern provinces - recalls great moments in the Roman conquest

16 Claudian asserts that Eutropius should be a devotee of Cybele rather than Mars (1.277). Thus Claudian also taps into a long tradition of hostile Roman rhetoric concerning the galli: on this see for instance Shaun Tougher, "The Aesthetics of Castration: The Beauty of Roman Eunuchs," in Castration and Culture in the Middle Ages, ed. Larissa Tracy (Cambridge, 2013), pp. 48-72, esp. pp. 51-6. Interestingly Cybele also features in the second invective, as an appropriate commentator on affairs in Phrygia: 2.279-303.

Ignoring (or perhaps simply ignorant of) such figures as Hermias the tyrant of Atarneus and the Attalid dynast Philetaerus (just as his point that there are female deities but no eunuch deities ignores Attis: 1.326). For these cases see for instance Guyot, Eunuchen, pp. 207-209 and 219-20. This assertion that eunuch rulers are unheard of even in the east echoes the remarks ascribed to the satrap Orxines about Bagoas the eunuch of Alexander the Great, in Quintus Curtius Rufus' History of Alexander 10.1.37, "I had heard that women once were rulers in Asia but this really is something new - a eunuch as king!", trans. John Yardley, Quintus Curtius Rufus, The History of Alexander (London, 2004), p. 240. Mary Renault, The Nature of Alexander (London, 1975), p. 197, notes the ridiculousness of this remark given recent Persian history, for another eunuch, also called Bagoas, had held sway. For Renault's depiction of Bagoas in the second novel of her Alexander the Great trilogy, see for instance Shaun Tougher, "The Renault Bagoas: The Treatment of Alexander the Great's Eunuch in Mary Renault's The Persian Boy," New Voices in Classical Reception Studies 3 (2008), 77-89. For Quintus Curtius Rufus and his history of Alexander (the only Latin history of Alexander, dating to the first century AD - either the reign of Claudius or Vespasian) see Elizabeth Baynham, Alexander the Great: The Unique History of Quintus Curtius Rufus (Ann Arbor, MI, 1998). Curtius' history is meant to speak to a Roman audience about imperial rule, and the role of the eunuch informs this subject: see also Tougher, "The Aesthetics of Castration," pp. 67-9. 
of the east, emphasising that Rome in the west had claim to the eastern territories. He asks:

Did Attalus make you, Rome, his heir, was Antiochus confined within the appointed bounds of Taurus, did Servilius enjoy a triumph over the hitherto unconquered Isaurians, did Egypt fall before Augustus, and Crete before Metellus, to ensure Eutropius a sufficient income? Cilicia, Judaea, Sophene, all Rome's labours and Pompey's triumphs, are there to sell $\left(1.215^{-221)}\right.$.

Ultimately Roma urges Stilicho to military action, to conquer Eutropius; she asks: "Why, Stilicho, dost thou delay to conquer because ashamed to fight [against a eunuch]?" (1.500-501).

Turning to the second invective, although it was completed after the exile of Eutropius, it still engages with notions of east and west, and urges the prospect of the salvation of the east by Stilicho. Claudian announces in his preface that the eunuch has been rejected by both parts of the empire, observing that he was never of the west (Hesperius) but is now repudiated too by the east (Eous) (2, Preface $35^{-36}$ ). In the body of the invective Claudian then relates the divine plan to deal with the problem of the east when Eutropius was still in power: Mars addresses Bellona, declaring:

'Sister, shall we never succeed in curing the East of effeminacy (molitiae)? Will this corrupt age never learn true manliness (rigescent $)^{18}$... The year that has known no war has had a eunuch for its consul. The consulship would have been at an end had a like spirit animated Italy (Hesperiis); this age-long office had fallen amid mockery and no traces been left of its trampled rights, had not Stilicho, heedful of the empire and of the character and morals of a past age, banished from Tiber's city this shameful name and kept Rome unsullied by an unheard of crime. He has given us a harbour to which the exiled majesty of Latium and the disgraced fasces might retire; he has given us annals wherein, abandoning the East (Oriente), an age polluted with servile stains might find a refuge' (2.112-32).

Bellona is then despatched to rouse barbarians (Gruthungi) against the east (i.e. Tarbigilus' revolt in Phrygia in 399).

Claudian contrasts the effeminate eastern army under the general Leo with that of Stilicho, which 
endured under arms the frosts of Thrace and were wont to winter in the open air and break with their axes the frozen waters of Hebrus for a draught. Changed is the leader and changed their character. Byzantium's luxury and Ancyra's pomp have destroyed their vigour (2.411-416).

Stilicho is held up as the potential saviour of the east (2.501 onwards). Claudian declares: "To him they look as to a star amid this universal shipwreck of war; to him innocent and guilty alike address their prayers" (507-8). Aurora, the goddess of the dawn, acts: "Thereupon suppliant Aurora turned her flight towards powerful Italy" $\left(2.5^{26-7)}\right.$ and goes to Stilicho. She clutches his "victorious hand" (manum victricem) (2.532). The remainder of the second invective is her appeal to Stilicho. She asks, why does he only care for Italy (Hesperiam), although he was once her "guide and ... leader" (2.535-6) (emphasising Stilicho's previous presence in the east prior to his departure to the west with Theodosius I in 394, to put down Eugenius). She blames Rufinus for the rupture of the two empires, a division maintained by Eutropius. "The world had begun to form one single empire under the rule of the two brothers" (fraterno coniungi coeperat orbis imperio), she says - but Eutropius prevented this (so unity is presented as Stilicho's goal) - and exclaims "In thee is now my only hope" (In te iam spes una mihi) $(2.591) \cdot{ }^{19}$ She begs:

do not condemn all for the fault of a few ... I seek not to draw thee away from Italy; thou art enough defence for both empires. Let both have the benefit of thine illustrious arms; let the same shield defend us and one hero work the salvation of a twofold world (2.599-602).

Thus, Claudian is not positing a permanent rupture of east and west; rather he conjures up a temporary state of affairs, caused by the influence of Rufinus and Eutropius. In the first invective he asked Eutropius: "Why seek to divide the two empires and embroil loving brothers in strife?" (1.281-2); and Roma desired the unity of the empire, complaining that "The discordant East (discors Oriens) envies our prosperity, and beneath that other sky (alio Phoebi), lo! wickedness flourishes to prevent our empire's breathing in harmony with one body" (1.398). The ultimate goal is the reunification of east and west, under Stilicho, though on his terms, of course. in Star Wars (1977): "Help me Obi-Wan Kenobi. You're my only hope." 


\section{Claudian and Roman Orientalism}

However, it is the subject of eunuchs that is the key focus of my analysis, and Claudian is famously not alone in identifying them as an aspect of imperial rule in the fourth century; for instance, it is well known that both Ammianus Marcellinus and the Historia Augusta are less than happy about the power and influence that eunuchs could exert with emperors. ${ }^{20}$ Both Ammianus and the authors of the Historia Augusta also associate the invention and use of eunuchs with the near east. Like Claudian, Ammianus attributes the first creation of eunuchs to the Assyrian queen Semiramis (14.6.17). The Historia Augusta, noting that Severus Alexander did not employ eunuchs in council or as ministers, remarks:

[T] hese creatures alone cause the downfall of emperors, for they wish them to live in the manner of foreign nations or as the kings of the Persians, and keep them well removed from the people and from their friends, and they are go-betweens, often delivering messages other than the emperor's reply, hedging him about, and aiming, above all things, to keep knowledge from him. ${ }^{21}$

However, Claudian's remarks are more specific, for they place eunuchs in the context of conflict between east and west within the Roman empire. A better parallel that quickly comes to mind is that of Augustan propaganda relating to his conflict with Antony and the Hellenistic queen Cleopatra VII. ${ }^{22}$ In his Life of Antony, Plutarch appears to reflect such propaganda, asserting

Octavius Caesar ... had a decree passed declaring war on Cleopatra and depriving Antony of the authority which he had allowed a woman to exercise in his place. Octavius Caesar also gave it out that Antony had allowed himself to fall under the influence of drugs, that he was no longer

See for instance Shaun Tougher, "Ammianus and the Eunuchs," in The Late Roman World and its Historian: Interpreting Ammianus Marcellinus, eds. David Hunt and Jan Willem Drijvers (London and New York, 1999), pp. 64-73; Alan Cameron, "Eunuchs in the 'Historia Augusta,"' Latomus 24 (1965), 155-8.

Historia Augusta 18.66.3-4, trans. David Magie, The Scriptores Historiae Augustate, 2 (London, 1924), p. 311.

22 Ware, Claudian, p. 76 n. 41, comments "While Romans had always viewed the East as decadent and effeminate, Lucan - and later Claudian - here relied on specifically anti-Egyptian prejudice encouraged in the propaganda of Augustus: on Cleopatra, for example, Aen. 8.685-8; Hor. Carm. 1.37." 
responsible for his actions, and that the Romans were fighting this war against Mardian the eunuch, Potheinus, Iras, who was Cleopatra's hairdresser, and Charmian, her waiting-woman, since it was they who were mainly responsible for the direction of affairs. ${ }^{23}$

Significantly, Claudian himself appears to have the case of Egypt in mind. As already noted, he refers to the fall of Egypt to Augustus. He also has Roma recall the case of the Ptolemaic eunuch Potheinus, who was responsible for the death of Pompey the Great, and has her identify Eutropius as a new Potheinus: Roma exclaims

The slaves of Egypt's kings [lit. "the Ptolemies"] have ever been a curse to the world; behold I suffer from a worse than Pothinus and bear a wrong more flagrant than that of which Egypt was once the scene. Pothinus' sword at Alexandria spilled the blood of a single consul; Eutropius brings dishonour on us all (1.480-484).

Thus Eutropius is compared with Potheinus, but is also declared to be far worse than him.

The example of Potheinus also points to a specific literary model for Claudian, as Catherine Ware has indicated: Lucan's De bello civili. She remarks

That Eutropius was a eunuch no doubt prompted Claudian to describe him as a more villainous Pothinus...In Lucan's De bello civili Pothinus features as the evil counsellor of the young Ptolemy, responsible for the death of Pompey...In [a] brief allusion to Lucan [8.536-8], Claudian prefigures the eunuch's evil grasp of power, the feebleness of the young emperor, and the readiness of his court to commit crimes against Rome ... By suggesting that Eutropius is a latter-day Pothinus, Claudian implied that the East, ruled by Pothinus/Eutropius, has turned away from the Roman mos maiorum. ${ }^{24}$

Plutarch, Life of Antony 6o, trans. Ian Scott-Kilvert, Plutarch, Makers of Rome (Harmondsworth, 1965), p. 326 .

24 Ware, Claudian, pp. 75-6. Lucan 10.133-5 also refers to the presence of eunuchs at Cleopatra's court: "There too were hapless boys who had lost their manhood by the knife; and opposite them stood youths, whose cheeks, in spite of their age, were scarce darkened by any down" ("Nec non infelix ferro mollita iuventus/ atque exsecta virum: stat contra fortior aetas/vix ulla fuscante tamen languine malas"), trans. J.D. Duff, Lucan (Cambridge, Mass., and London, 1928), p. 601. Dilke, Claudian, p. 11, also points to the debt of Claudian's invectives to Lucan. 
It is perhaps telling too that Claudian names one of the lovers of Eutropius as a certain Ptolemy; ${ }^{25}$ it is certainly intriguing that Ammianus also appeals to the example of the death of Pompey, asserting that he was "butchered in Egypt to give the eunuchs pleasure" (14.11.32). ${ }^{26}$

\section{Court Eunuchs before 395}

In relation to assessing dis/unity between east and west in the fourth century it is vital also to consider the reality of the eunuch presence in the Roman Empire in this period. Regarding the use of eunuchs at the imperial court before 399, as noted above, Roma acknowledges that eunuchs had become part of the Roman world

ever since the court exalted itself with Arsacid pomp and the example of Parthia corrupted our morals. But till now they were but set to guard jewels and raiment, and to secure silence for the imperial slumber. Never beyond the sleeping-chamber did the eunuch's service pass; not their lives gave guarantee of loyalty but their dull wits were a sure pledge. Let them guard store of pearls and Tyrian-dyed vestments; they must quit high offices of state (1.414-423).

The precise date of the institutionalisation of court eunuchs in the Roman empire is debated, though often associated with the figure of Diocletian and his supposed transformation of imperial style. The first well-documented case of a powerful court eunuch, however, is that of Eusebius, the grand chamberlain of Constantius II, and the main forerunner of Eutropius. He is presented by several sources - but most famously Ammianus - as the controller of Constantius, as the real power at the heart of the empire. ${ }^{27}$ Such was Eusebius' significance that some sources even confuse Eusebius of Nicomedia, the "Arian"

\footnotetext{
25 As Long, Claudian's In Eutropium, p. 124, remarks. See also the comments of Schweckendiek, Claudians Invektive gegen Eutrop, p. 107.

26 Trans. John C. Rolfe, Ammianus Marcellinus, 1 (Cambridge, Mass., 1950), p. 109. The observation is made in a series of examples to show the fickleness of Fortune, in relation to the death of the Caesar Gallus (whose fall and death the grand chamberlain Eusebius and other eunuchs were implicated in). The death of Pompey at the hands of a eunuch seems to have been a familiar example in late antiquity of the fickleness of Fortune: Ambrose in his formal reply to Symmachus' famous appeal for the restoration of the altar of Victory also utilises it (Ep. 73.35).

27 See for instance Tougher, Eunuch, pp. $3^{6-7}$.
} 
bishop so influential with Constantine and Constantius II (not to mention Licinius and his wife Constantia), with him. ${ }^{28}$ It is important to appreciate that the eunuch Eusebius was active in both eastern and western parts of the empire, and also that both Constantius' Caesares, Gallus and Julian, had grand chamberlains too, Gorgonius and Eutherius respectively. ${ }^{29}$ The case of Eutherius is especially instructive when considering issues of east and west. Commenting on Eutherius' background and career, Ammianus remarks:

He was born in Armenia of free parents, but when still very young he was kidnapped by hostile tribesman in that neighbourhood, who gelded him and sold him to some Roman traders, who brought him to Constantine's palace (ad palatium Constantini). There, as he grew up, he gradually gave evidence of virtuous living and intelligence ... And if the emperor Constans had listened to him in times past, when Eutherius had grown up and was already mature, and urged honourable and upright conduct upon him, he would have been guilty of no faults, or at least only pardonable ones $(16.7 \cdot 5){ }^{30}$

Thus not only had Eutherius begun his career under Constantine, but Constans had been served by the eunuch - in the western empire. It is interesting to consider what activities Eutherius was engaged in, between the murder of Constans in 350 and the appointment of Julian as Caesar in Gaul in 355. Presumably, he joined the court of Constantius in the west when the emperor made his way there, perhaps entering the service of Constantina before the arrival of her brother.

Thus Claudian's attempts to present eunuchs purely as low-level and dim domestic staff, and as alien to the west, are (unsurprisingly) disingenuous, to say the least (despite the efforts of the emperors Julian and Magnus Maximus). ${ }^{31}$ Further, one can also make the case that it was the consumption of eunuchs as luxury slaves in Rome by the imperial court from its very beginnings (and probably by the elite prior to the advent of Augustus) that created the eventual institutionalisation of court eunuchs, rather than Persia simply

28 See for example David Hunt, "Did Constantius II have 'Court Bishops'?," Studia Patristica 19 (1989), 86-9o, esp. 87.

29 For Gorgonius see Amm. Marc. 15.2.10.

30 Trans. Rolfe, Ammianus, pp. 227-9.

$31 \quad$ Both these emperors seem to have been keen to curtail the role of eunuchs at the imperial court: see for example Tougher, Eunuch, pp. 39-40. 
being suddenly copied. In effect, the development started in Rome itself, albeit under Hellenistic influence. ${ }^{32}$

\section{Court Eunuchs after 399}

It is also instructive to look beyond the case of Eutropius to consider the presence of eunuchs in the west after 399. They evidently remained a consistent and significant feature of the court, as seen in the examples of Terentius the praepositus sacri cubiculi of Honorius, and Acolius the praepositus sacri cubiculi of Valentinian III. $^{33}$ It is telling that court eunuchs continued to be utilised in Italy under Theoderic the Ostrogoth, witness the funerary inscription commemorating the eunuch chamberlain Seda. ${ }^{34}$

However, I will conclude this chapter by looking even further ahead into the sixth century, to consider the case of Narses, as this makes an intriguing contrast with the case of Eutropius. Narses, a eunuch from Persarmenia, is famous as the vanquisher of the Ostrogoths, having been sent by Justinian I in Constantinople to take command of the campaign in Italy in 551, despite having served in the traditional roles of chamberlain and treasurer. ${ }^{35}$ For the latter stages of Narses' career and life in Italy, where he had become de facto ruler as Justinian's leading official there, we are primarily dependent on a variety of western sources, such as Gregory of Tours' History of the Franks, the Book of Pontiffs, and Paul the Deacon's History of the Lombards. It is well known that in accounts of the Lombard invasion of Italy in 568 Narses is implicated in bringing this about by summoning the Lombards in. One might then expect the western sources to trot out all the old clichés about eunuchs and the east, but they are more nuanced than that, and can seem to feel some sympathy for the eunuch. The Book of Pontiffs praises Narses for his defeat of Sindual king of the Heruli and Amingus dux of the Franks, asserting that "the whole of Italy was

32 See for example Tougher, "The Aesthetics of Castration," pp. 69-70; Walter Stevenson, "The Rise of Eunuchs in Greco-Roman Antiquity," Journal of the History of Sexuality 5 (1995), 495-511. See further Shaun Tougher, Roman Castrati: Eunuchs in the Roman Empire (forthcoming).

33 For Terentius see Zosimus 5·37-4-6. For Acolius see PLRE 2, Ac(h)olius, p. 6. For eunuchs in the western Roman empire in the fifth century see for instance Tougher, Eunuch, p. 42.

34 PLRE 2, Seda, p. 987. The inscription, at Ravenna, reads: "Hic requiescit in pace vir s[u] bl[imis] Seda ignucus et cubicularius regis Theoderici” (CIL 11, 64 no. 310).

For Narses see for instance PLRE 3B, Narses 1, pp. 912-28; Dunlap, "Grand Chamberlain," pp. 284-99; Lawrence Fauber, Narses: Hammer of the Goths (New York and Gloucester, 1990). 
glad."36 However, it then relates that the Romans "driven by malice" complained to Justin II and Sophia (who had become rulers after the death of Justinian in 565) that Narses treated them like slaves, and asked that he be recalled or they would go over to the "barbarians". ${ }^{37}$ Discovering what had occurred Narses declared "If I have maltreated the Romans let me suffer evil," left Rome for Campania and "wrote to the Lombard nation to come and occupy Italy". The seventh-century chronicle of Fredegar contains an expanded version of the story (4.65), asserting that it was because Narses was terrified by the threats of Justin and Sophia that he summoned the Lombards into Italy. ${ }^{38}$ Sophia had instructed that a golden spindle should be made for him, since he was a eunuch and should rule over slaves not peoples; Narses remarks "I shall spin a thread of which neither the emperor Justin nor the empress can find the end"'. Paul the Deacon, writing in the eighth century, includes a further elaborated narrative (2.5) ${ }^{39}$ Once again Narses is the victim of the Romans, who are said to have envied him despite all his labours. The imperial response is more fully described. The emperor Justin II is reported to have been very angry with Narses and to have despatched Longinus ${ }^{40}$ to replace him, and the empress Sophia is said to have sent him a threatening message, addressing the fact that he was a eunuch: she said "that she would make him portion out to the girls in the women's chamber the daily tasks of wool." ${ }^{\text {11 }}$ Narses is reputed to have retorted to this "that he would begin to weave her such a web as she could not lay down as long as she lived." In the versions found in Fredegar and Paul, then, Narses' invitation to the Lombards is the result of fear and hatred of the imperial couple, not of a wish to teach the Romans a lesson.

Thus in these western sources on Narses there is encountered a nice inversion of the old western orientalist approach to eunuchs: the eunuch becomes a hero, and the victim of the envy of westerners and the subject of the hostile rhetoric of the eastern court: it is ironic that it is the east that threatens to oust Narses from power and confine him to domestic and feminine chores. Like

$36 \quad$ Liber Pontificalis, John III, trans. Raymond Davis, The Book of Pontiffs (Liber Pontificalis). The Ancient Biographies of the First Ninety Roman Bishops to AD 715 (Liverpool, 1989), p. 60. Though it names Justinian as the emperor, rather than Justin.

38 Isidore of Seville, Chronicon 116, also says that Narses was terrified by Sophia's threats, but does not reveal what they are.

For Paul and his history see for instance Walter Goffart, The Narrators of Barbarian History (A.D. 550-8oo):Jordanes, Gregory of Tours, Bede, and Paul the Deacon (Princeton, NJ, 1988), pp. 329-431.

41 Trans. William Dudley Foulke in Paul the Deacon, History of the Lombards, ed. Edward Peters (Philadelphia, PA., 2003), p. 59. 
Claudian's Eutropius, Narses is a eunuch who is a ruler, but one in the west and one that merits respect.

\section{Conclusion}

For Claudian - and Stilicho - Eutropius was a useful and easy target of attack, as a eunuch who had acquired a powerful position at the court of Constantinople. Claudian was presented with a gift of a subject, and tapped into long established orientalist Roman rhetoric to attack the eunuch and also the government of the east. However, perpetual disunity was not envisioned, but rather the reunification of the empire, under Stilicho. Further, it is clear that court eunuchs, and politically important ones at that, were not confined to the eastern empire but were just as home in the west too. Eusebius the grand chamberlain of Constantius II, operated in both spheres, and under the Constantinian dynasty Eutherius had had a career in the west too. Indeed eunuchs had been a feature of the imperial court as far back as the time of Augustus, and probably before this had been employed in elite households. The tradition of the court eunuch was to remain part of the western Roman court for the fifth century, and continued also in Italy under Theoderic the Ostrogoth into the sixth century. After the reconquest of the west under Justinian a eunuch was even to rule in Italy, and emerge as something of a hero in western sources, which present him as being vilified by the eastern court. Thus the figure of the eunuch could be exploited as a symbol of disunity and represent the effeminate east in opposition to the manly west, but could also serve other ends; all depended on context and the motivations of authors. In reality the eunuch was a consistent and persistent aspect of both parts of the Roman Empire in Late Antiquity, a symbol not of division but of unity as a defining feature of Roman culture.

\section{Bibliography}

Elizabeth Baynham, Alexander the Great: The Unique History of Quintus Curtius Rufus (Ann Arbor, MI, 1998).

Roger Blockley, The Fragmentary Classicising Historians of the Later Roman Empire:

Eunapius, Olympiodorus, Priscus and Malchus, 2 (Liverpool, 1983).

Alan Cameron, “Eunuchs in the 'Historia Augusta', Latomus 24 (1965), 155-8.

—_, "Notes on Claudian's Invectives," Classical Quarterly 18 (1968), 387-411.

— Claudian. Poetry and Propaganda at the Court of Honorius (Oxford, 1970). 
Raymond Davis, The Book of Pontiffs (Liber Pontificalis). The Ancient Biographies of the First Ninety Roman Bishops to AD 715 (Liverpool, 1989).

Oswald Ashton Wentworth Dilke, Claudian: Poet of Declining Empire and Morals; An Inaugural Lecture (Leeds, 1969).

J.D. Duff, Lucan (trans.) (Cambridge, Mass., and London, 1928).

James E. Dunlap, "The Office of the Grand Chamberlain in the Later Roman and Byzantine Empires," in Two Studies in Later Roman and Byzantine Administration (New York and London, 1924), pp. 161-324.

Lawrence Fauber, Narses: Hammer of the Goths (New York and Gloucester, 1990).

William Dudley Foulke (trans.) in Paul the Deacon, History of the Lombards, ed. Edward Peters (Philadelphia PA., 2003).

Florence Garambois-Vasquez, Les invectices de Claudian. Une poétique de la violence (Brussels, 2007).

Walter Goffart, The Narrators of Barbarian History (A.D. 550-80o):Jordanes, Gregory of Tours, Bede, and Paul the Deacon (Princeton, NJ, 1988).

Marie-France Guipponi-Gineste, Claudien. Poète du monde à la cour d'Occident (Paris, 2010).

Peter Guyot, Eunuchen als Sklaven und Freigelassene in der griechisch-römischen Antike (Stuttgart, 1980).

Keith Hopkins, "Eunuchs in Politics in the Later Roman Empire," Proceedings of the Cambridge Philological Society 189 (1963), 62-80.

- Conquerors and Slaves (Cambridge, Eng., 1978).

David Hunt, "Did Constantius II have 'Court Bishops'?, Studia Patristica 19 (1989), 86-9o.

Natalie Kampen, Family Fictions in Roman Art (Cambridge, Eng., 2009).

David Magie, The Scriptores Historiae Augustae 2 (trans) (London, 1924).

Maurice Platnauer, Claudian, 1 (Cambridge, Mass., 1922).

John C. Rolfe, Ammianus Marcellinus 1 (trans.) (Cambridge, Mass., 1950).

Helga Scholten, Der Eunuch in Kaisernähe: zur politischen und sozialen Bedeutung des praepositus sacri cubiculi im 4. und 5. Jahrhundert n. Chr. (Frankfurt, 1995).

Helge Schweckendiek, Claudians Invektive gegen Eutrop (In Eutropium). Ein Kommentar (Hildesheim, 1992).

Ian Scott-Kilvert, Plutarch, Makers of Rome (Harmondsworth, 1965).

Walter Stevenson, "The Rise of Eunuchs in Greco-Roman Antiquity," Journal of the History of Sexuality 5 (1995), 495-511.

Shaun Tougher, "Ammianus and the Eunuchs," in The Late Roman World and its Historian: Interpreting Ammianus Marcellinus, eds. David Hunt and Jan Willem Drijvers (London and New York, 1999), pp. 64-73. 
, "Two Views on the Gender Identity of Byzantine Eunuchs," in Changing Sex and Bending Gender, eds. Alison Shaw and Shirley Ardener (New York and Oxford, 2005), pp. 60-73.

- The Eunuch in Byzantine History and Society (London and New York, 2008).

— , "The Renault Bagoas: The Treatment of Alexander the Great's Eunuch in Mary Renault's The Persian Boy," New Voices in Classical Reception Studies 3 (2008), 77-89.

- "The Aesthetics of Castration: The Beauty of Roman Eunuchs," in Castration and Culture in the Middle Ages, ed. Larissa Tracy (Cambridge, 2013), pp. 48-72.

- Roman Castrati: Eunuchs in the Roman Empire (forthcoming).

Catherine Ware, Claudian and the Roman Epic Tradition (Cambridge, Eng., 2012). 